\title{
Заметки о возрасте трех братьев-венгров - Ефрема, Моисея и Георгия - и времени их прихода на Русь
}

\author{
ВАЛЕРИЙ ЛЕПАХИН \\ LEPAHIN Valerij, SzTE Szláv Tanszék, Szeged, Egyetem u. 2, H-6722
}

\begin{abstract}
This paper argues for a reconsidering of the generally accepted age of Moses Ugrin: not 60 years in 1043, in the year of his death, but around 45 years. The author specifies also "the black spot" in the biography of Moses and argues with Plotnikoff, the author of the novel "George Ugrin", concerning the age of George, the younger brother of Moses. He also offers in the article the specification of the time and the reasons of the arrival in Russia of the three Hungarian brothers, Ephraim, Moses and George. The author believes that the most probable time of their arrival is the year 1008 and declines to accept the hypothesis about their Transylvanian, rather than Moravian origin.

Keywords: Hungarian-Russian relations, Old Russian literature, legends of saints, George Ugrin, Moses Ugrin, icons
\end{abstract}

Нам хотелось бы обратить внимание ислледователей жизни трех венгерских святых на некоторые проблемы, возникающие при попытках уточнить возраст всех трех братьев.

Менее всего спорны вопросы, связанные с возрастом Ефрема. Согласно всем церковным календарям и древним святцам он скончался в 1053 г. Жития его уточняют, что скончался он в глубокой старости (Житие 1916: 171; Минея 1983: 447). Иногда называется и приблизительная цифра - 70 лет. Таким образом, можно предположить, что старший брат - прп. Ефрем - родился в начале 80 -х годов $\mathrm{X}$ в. (назвать точную дату - 1883 г. - было бы слишком опрометчиво). Прп. Ефрем, как старший по возрасту, скорее всего и привел младших братьев с собою на Русь. Будучи главным конюшим у князя Бориса, он мог содержать и братьев ${ }^{1}$.

В хронологии жизни второго брата — прп. Моисея — есть неувязки,

1 Упоминание о должности старшего конюшего встречается уже в краткой редакции «Русской Правды» (XI в.): за убийство «мужем мужа» полагалась вира в 40 гривен, «а конюхъ старый оу стада 80 гривенъ, яко оуставилъ Изяславъ», т.е. за убийство старшего конюха (конюшего) налагалась двойная вира. В пространной редакции говорится: «Аже въ княжи отроци или въ конюсе или въ поваре, то 40 гривенъ, а за тиунъ за огнищный и за конюшии, то 80 гривенъ» (см.: Юшков 1950: 203-204, 207). И здесь, как видим, за убийство конюшего назначается двойная вира по сравнению с простым конюхом или княжеским отроком, каковым был, кстати, Георгий Угрин. (Позже при Иване III конюший назначался только из бояр, а при Иване Грозном конюший по своей должности считался первым среди других приближенных бояр). На основе этих сведений можно предположить, что братья были скорее всего знатного происхождения. 
на которые стоит обратить внимание. Впервые три брата упоминаются в 1015 г.: Моисей и Георгий в связи с убийством князя Бориса, а прп. Ефрем без соотнесения с братьями в том же 1015 г. в Новгородской летописи: «Преподобный отецъ нашъ Ефремъ Новоторжский бъ въ сия времена» (Летописи 1879: 176). Следующая дата также известна: в 1018 г. Моисей попадает в плен (см. Библиотека 1997: 660). Через пять лет, согласно Киево-Печерскому патерику, т.е. в 1023 г., его покупает женщина-вдова, воспылавшая страстью к красивому юноше (Моисей 1997: 419). Вероятно, в следующем 1024 г. его постригает пришедший с Афона иеромонах, а в 1025 г., как известно, умирает польский король Болеслав (Библиотека 1997: 662). Но восстание в Польше, о котором сообщает Киево-Печерский патерик, произошло не сразу после смерти Болеслава, а в 1031 г. (Библиотека 1997: 662). И как раз в 1031 г. многие пленники, благодаря Ярославу Мудрому, вернулись из Польши в Киев. Некоторые источники сообщают, что Моисей пришел к прп. Антонию как раз в 1031 г. (Минея 1988: 148)2. Тогда можно предположить, что он два года проходил послушания в монастыре, а с 1033 г. до своей кончины в 1043 г. подвизался в пещере, поскольку его житие сообщает, что он прожил в монастыре десять лет (Библиотека 1997: 427). Так обнаруживается, что ничего неизвестно об одном довольно длительном периоде из жизни Моисея: от смерти Болеслава в 1025 г., до его прихода к Антонию в 1031 г. В житии говорится, что Моисей страдал пять лет в оковах (до знакомства с женщиной) и шестой год «за чистоту» (Библиотека 1997: 427). Итак, у вдовы он был год, а всего в плену с 1018 по 1025 г. Если женщину убили во время восстания 1031 г., то она всё это время была жива и тогда Моисей находился в плену, но об этом нигде не упоминается. В житии и в других источниках говорится, что Моисей пришел в Киев, «оправившись от ран» (Библиотека 1997: 427)³. Возможно ли, что после оскопления эта женщина отпустила Моисея и он около шести лет где-то восстанавливал свое здоровье, чтобы начать монастырскую жизнь? Или женщину убили не во время восстания 1031 г., а сразу после смерти Болеслава? Или он еще пять лет оставался в раб-

\footnotetext{
2 «Бъ бо пришель блаженный (Моисей в монастырь. - В. Л.) въ дьни святаго Антониа» - сообщает его житие (Библиотека 1997: 427). Прп. Антоний вернулся с Афона в 1028 г., следовательно прп. Моисей пришел к нему в пещеру после этой даты. Вероятно, в монашеской жизни они были одного духовного устроения и во многом единомысленны, ведь скончался прп. Моисей еще при жизни прп. Антония, и рассказ о подвигах Моисея включили в житие основателя Киево-Печерского монастыря. Во всяком случае можно предположить, что прп. Моисей по своему духовному устроению был ближе к Антонию, чем к Феодосию.

3 Тверская летопись сообщает коротко: «Моисей же, по страдании своимь, прииде въ Киевъ, Печерский манастырь...» (Тверская 1965: 137). В Минее же говорится: «Преподобный Моисей был настолько измучен и истерзан, что только через несколько лет, после улучшения здоровья, отправился в Киев» (Минея 1988: 148). Но откуда отправился Моисей в Киев, также не сообщается.
} 
стве и лишь год восстанавливал свое здоровье? ${ }^{4}$ Пока на эти вопросы ответов нет.

Другая проблема связана с возрастом Моисея. Дата его кончины известна - 1043 г., за десять лет до кончины старшего брата Ефрема. В некоторых источниках говорится, что Моисей прожил 60 лет (Патерик 1903: 116). Значит он родился приблизительно в 983 г. Но в этом случае он попал бы в плен в 35-летнем возрасте, а женщина увидела бы его сорокалетнего (через пять лет плена, согласно Патерику). Однако, в житии он называется юношей: так его называют и друзья-советчики, и женщина (см. Библиотека 1997: 420, 424)5. В Древней Руси возрастная шкала выглядела следующим образом: до семи лет - дитя, до 14-15 - отрок, до 21 - юн, до 28-30 млад, далее - средовек, стар и дряхл. Например, князя Бориса тексты называют обычно «млад», Глеба - «юн», а Георгия - «отрок». При исчислении возраста Моисея надо, на наш взгляд, исходить из двух известных дат: 1023 г. (в плену Моисея покупает полячка и он еще юн) и 1043 г. (дата кончины). Поэтому можно полагать, что Моисей был на 15-20 лет моложе, чем это принято думать и родился на рубеже тысячелетий, а скончался, следовательно, примерно в возрасте сорока пяти лет 6 .

В связи с этим возникают вопросы и относительно возраста Георгия. $\mathrm{B}$ упоминавшейся в предыдущей статье повести Плотникова Георгий умирает 23-летним. Нам кажется, что это совершенно нереальная цифра. Георгий был на несколько лет моложе Моисея. Во всех источниках Георгий называется отроком. Слово отрок в древнерусском языке имело несколько значений: им обозначали и возраст (как выше говорилось, это подросток от 7 до 15 лет), и должность княжеского слуги, и княжеского дружинника, молодого воина (см. Даль² 2, 751; Срезн 2, 764; Словарь 1988: 19-21). Великовозрастного слугу, которому было больше 15 лет, называли отрочищь или отрочище (см. Даль² 2,751$)$. По отношению к Георгию это слово, как можно полагать, употребляют во всех трех смыслах, т.е. он отрок по возрасту, он княжий слуга, конюший, а также воин (об этом можно заключить из того, что он носил гривну и посчитал своим долгом остаться со своим господином до конца). Итак, Георгию, которого называют всегда только отроком, к моменту убийства не могло быть больше 15-16 лет. Поэтому можно считать, что Моисей родился приблизительно в 997-998 гг., а Георгий — в 1000-1001 гг.

Остается немало вопросов и отосительно точного времени прихода трех братьев на Русь и поступления на службу к ростовскому князю

4 Тогда получилось бы в общей сложности одиннадцать лет плена, чему противоречит сообщение жития о шести годах.

${ }^{5}$ В оригинале Моисей два раза называется юношей, в переводе же на современный руский язык в Библиотеке литературы Древней Руси - пять. Вместе с тем юн там переведено как 'молод'.

${ }^{6}$ Иштван Иванчо щитает, что Моисей родился между 990 и 995 годами (см. IVANCSÓ István, Magyar Mózes liturgikus tiszteletének tükrében. Nyíregyháza 1997, 43). 
Борису. Имеются сведения, что они оставили отечество по религиозным причинам (Преподобный 1885: 2; Акафисты 1995: 113-114; Свешников 1988: 49). О мотивах, по которым братья покинули Венгрию и об их возможном трансильванском происхождении пишет Иштван Феринц7; он также указывает предположительное время их переселения в Ростов - или в конце Х в., или между 1003-1008 гг. (см. Феринц 1993: 19-25). Нам кажется, что предположения И. Феринца довольно убедительны и обоснованы. Мы собираемся лишь уточнить некоторые детали и высказать несколько предположений. Известно, что еще в X в. венгерские князья Булчу, Дьюла и Айтонь приняли Христианство от Византии ${ }^{8}$ В Вплне вероятно, Ефрем, Моисей и Георгий были выходцами с территорий, лежавших на юг от Тисы по обоим берегам реки Марош вплоть до трансильванских гор. Эти земли принадлежали князю Дьюле - дяде по матери короля Иштвана9. В 1003 г. Иштван совершил поход против независимого княжества ${ }^{10}$, захватил Дьюлу с двумя сыновьями в плен и силой принудил переход князя и населения его княжества в Христианство. На деле же для части населения, уже крещенного по византийскому обряду, это означало насильственный переход на непривычный латинский обряд ${ }^{11}$.

Но еще более вероятно, что братья были выходцами из сильного, богатого и независимого княжества под управлением Айтоня со столицей в Марошваре; эти территории прилегали к владениям Дьюлы. Как сообщается в большом житии епископа Геллерта, Айтонь «был крещен в [болгарском] городе Видине [«Будин»] по обряду греков»12. В 1008 г.

${ }^{7}$ Напомним, что Н. Плотников выдвинул гипотезу о моравском или приморавском происхождении братьев.

8 Булчу и Дьюла крестились в Константинополе либо вместе в 948 г., либо сначала Булчу в 948 г., а после него Дьюла в 952-953 гг. Крестным отцом Булчу был византийский император Константин Багрянородный (см.: Шушарин 1988: 162). Никоновская летопись сообщает об этом так: «...Мановениемъ Божиимъ подвигошася два князя угорскаго языка, идоша въ Царьградъ, и прияша святое крещение и съ сущими подо областию ихъ. Архиереи же гречестии не доспевше внити въ землю ихъ варварскаго ради нашествия на Царьградъ» (Летопись 1965: 70).

9 Здесь речь идет о Дьюле, который остался язычником. Как говорит один из источников, король Иштван совершил поход против него потому, что он «не принял веры Христовой и не переставал наносить обиды венграм» (см. Шушарин 1988: 170).

10 Дьюла и Айтонь были связаны с Гезой (отцом Иштвана) преимущественно союзными отношениями, но не подчинительными.

11 Хотя официальное разделение Церквей произошло в 1054 г., но напряженные отношения между Константинополем и Римом начались еще в IX в. Вызваны они были различиями в учении об исхождении Святого Духа. Антилатинские трактаты появились тогда же. Тем более сильными могли быть антилатинские настроения в начале XI в. в тех областях, где византийские и римские миссионеры были не просто соперниками, но противниками и не раз вступали в открытую борьбу. Кстати, и венгрыязычники не раз восставали в начале XI в. под лозунгом борьбы против «латинян и немцев».

12 Цит. по: Шушарин 1988: 171. Далее в житии Геллерта говорится: «От греков же он (Айтонь. - B. Л.) получил полномочия и построил в упомянутом городе на Мароше 
Иштван организовал поход против Айтоня; во главе королевского войска стоял Чанад, бывший воевода Айтоня, бежавший к королю и крещенный им (Györffy 1977: 171-176). Айтонь погиб на поле брани. «Тела же павших в битве христиан, - повествует житие Геллерта, собрали, привезли в Марошвар и похоронили на кладбище в монастыре греков св. Иоанна Крестителя, так как в этой области в то время не было другого монастыря» (Шушарин 1988: 171). В 1009 г. Иштван посылает на бывшие территории Айтоня в качестве миссионера Бруно Квертфурского, который в том же году сообщал императору Генриху: «...Наши - да простит их Бог - некоторых ослепили, совершив большой грех» (Шушарин 1988: 176). Как можно полагать, скорее всего именно эти события в бывших владениях Айтоня, населенных христианами греческого обряда и язычниками (прежде всего попытки «перекрестить» христиан греческого обряда) и заставили трех братьев покинуть Трансильванию. Разумеется, они пришли крещеными по греческому обряду, поскольку были сразу приняты на службу к князю Борису, а в 1015 г. прп. Ефрем являлся, как уже говорилось, старшим конюшим Бориса.

Всё вышесказанное основано на глухих упоминаниях о преимущественно религиозных причинах переселения трех братьев на Русь. Но нельзя оставить в стороне и самое простое предположение. У великого князя киевского Владимира, как утверждают источники, были хорошие политические отношения с королем Иштваном, а венгры в те времена считались на Руси лучшими специалистами в области коневодства для военных целей. Как известно из летописей, великий князь Святослав в 969 г. хотел перенести свою столицу на Дунай; одной из причин переселения он называл близость Венгрии, из которой поступают кони, хорошо обученные для военных целей ${ }^{13}$. В упоминавшемся житии Геллерта говорится, что у Айтоня было «бесчисленное множество горячих коней, не считая тех, которых охраняли его пастухи в стойлах» (Шушарин 1988: 171). Эти данные заставляют учесть и такую возможность: старший из братьев Ефрем мог быть просто приглашен на службу великим князем Владимиром или князем Борисом в качестве специалиста по коневодству, и взял с собой младших братьев, поскольку родители к тому времени, видимо, умерли.

Всё сказанное позволяет предположить, что братья переселились скорее всего после событий 1008 г. (при условии трансильванского, а не приморавского их происхождения), когда Георгий начал входить в отроческий возраст. Дата переселения 1003 г. (и тем более конец X века), на наш взгляд, менее вероятны, поскольку Георгий был слишком мал для

монастырь в честь св. Иоанна Крестителя, поселив в нем аббата с греческими монахами, согласно их уставу и обряду» (Шушарин 1988: 171).

${ }^{13} \mathrm{O}$ желании Святослава переселиться на Дунай и его причинах сообщает «Повесть временных лет» (см.: Повесть 1978: 81-82). 
такого крутого перелома в своей судьбе, а в конце $\mathrm{X}$ в. его просто не было в живых. Вместе с тем, Ефрем за семь лет с 1008 до 1015 вполне мог достичь ответственной должности старшего конюшего у князя Бориса.

\section{Литература}

Акафисты 1995 - Акафисты русскимъ святымъ, 1-3. СПб. 1995.

Библиотека 1997 - Библиотека литературы Древней Руси. ХІІ век, 4. СПб. 1997.

Даль ${ }^{2}$ - Толковый словарь живаго великорусскаго языка Владимира Даля, 1-4. СПб.Москва 1880-82.

Летописи 1879 - Новгородские летописи. СПб. 1879.

Летопись 1965 - Полное собрание русских летописей, 9-10. Патриаршая или Никоновская летопись. Москва 1965.

Минея 1983 - Минея. Январь, часть вторая. Москва 1983.

Минея 1988 - Минея. Июль, часть третья. Москва 1988.

Моисей 1997 - О преподобном Моисее Угрине. Слово 30: Библиотека литературы Древней Руси. ХІІ век, 4. СПб. 1997.

Патерик 1903 - Киево-Печерский патерик. Москва 1903.

Повесть 1978 - Повесть временных лет: Памятники литературы Древней Руси, XI начало ХІІ века. Москва 1978.

Преподобный 1885 - Преподобный Ефрем, архимандрит, и Аркадий, ученик его Новоторжские чудотворцы: Тверские епархиальные ведомости, № 10. Тверь 1885.

Свешников 1988 - Свешников Вячеслав, протоиерей. В день памяти преподобного Ефрема Новоторжского: Журнал Московской Патриархии, № 7. Москва 1988.

Срезн - Срезневский И. И. Материалы для словаря древнерусского языка по письменным памятникам. СПб. 1 ( $A-K)$ 1893, 2 (Л-П) 1895, 3 (P-V) 1903, Дополнения (А-Я) 1912.

Феринц 1993 - Ферини И. Моисей Угрин и его братья: Studia Slavica Hung. 38 (1993) 19-25.

Шушарин 1988 - Шушарин В. П. Христианизация венгров: Принятие Христианства народами Центральной и Юго-Восточной Европы и крещение Руси. Москва 1988.

Юшков 1950 - Юиков С. В. Русская правда. Москва 1950.

Ferincz 1998 - FERINCZ I. Magyar Mózes és Efrém - az orthodox egyház szentjei: AETAS, 1998/1. Györffy 1977 - GYÖRFFY Gy. István király és müve. Budapest 1977.

Ivancsó 1997 - IVANCSÓ I. Magyar Mózes liturgikus tiszteletének tükrében. Nyíregyháza 1997.

Moravcsik 1988 - MORAVCSIK Gy. Az Árpád-kori magyar történet bizánci forrásai. Budapest 1988. Moravcsik 1953 - MORAVCSIK Gy. Bizánc és a magyarság. Budapest 1953. 